Vegetalika. 2018. 7(3): $16-29$

\title{
Pengaruh Dosis Urea terhadap Pertumbuhan dan Hasil Kedelai (Glycine max L. Merr.) Kultivar Anjasmoro
}

\author{
Effect of Urea Fertilizer Rates on Growth and Yield of \\ Soybean (Glycine max L. Merr.) cv. Anjasmoro
}

\author{
Dhimas Ikhsan Prakoso, Didik Indradewa*), Endang Sulistyaningsih \\ Departemen Budidaya Pertanian, Fakultas Pertanian, Universitas Gadjah Mada \\ *) Penulis untuk koresponden Email: didikindradewa54@yahoo.com
}

\begin{abstract}
Soybean has been known has an ability to convert $N$ from open air and developing it into material which can be used. But, in the field, farmer still using $N$ fertilizer in their cultivate activity to support plant in the beginning of growth phase. Anjasmoro variety is soybean cultivar which often used by farmer in cultivate activities because has a big seed morphology. The research was aimed to understand the effect of diffferent doses of $N$ fertilizer which use Urea to Anjasmoro and find optimum rate of Urea Fertilizer for Soybean plant's growth, development and yield. The researched was conducted in the field and arranged in randomized complete block design, urea doses level were 0 $\mathrm{kg} / \mathrm{ha}, 50 \mathrm{~kg} / \mathrm{ha}, 100 \mathrm{~kg} / \mathrm{ha}, 150 \mathrm{~kg} / \mathrm{ha}$, and $200 \mathrm{~kg} / \mathrm{ha}$. Data were analyzed using analysis of varians and continued using Duncan Multiple Range Test with significance level of $5 \%$. Result showed that Urea fertilizer lower leaf $N$ content. Different rates of Urea not affect but $205 \mathrm{~kg} / \mathrm{ha}$ Urea rate was optimum for net assimilation rate. Urea fertilizer did not affect to growth and yield of cv. Anjasmoro.
\end{abstract}

Keywords : anjasmoro soybean, urea dose level, nitrogen, growth, assimilate

\section{INTISARI}

Kedelai diketahui memiliki kemampuan untuk mengikat $\mathrm{N}$ dari udara, namun pada budidayanya di lapangan, pemupukan $\mathrm{N}$ masih dilakukan untuk mendukung pertumbuhan awal tanaman. Kultivar Anjasmoro banyak ditanam petani karena memiliki morfologi biji yang besar. Penelitian ini bertujuan untuk mengetahui pengaruh perbedaan dosis urea pada tanaman kedelai kultivar Anjasmoro serta menentukan takaran optimum untuk pertumbuhan dan hasil. Penelitian lapangan dilakukan dengan rancangan acak kelompok lengkap dengan perlakuan takaran pupuk urea yang terdiri dari 5 aras : $0 \mathrm{~kg} / \mathrm{ha}, 50 \mathrm{~kg} / \mathrm{ha}, 100 \mathrm{~kg} / \mathrm{ha}, 150 \mathrm{~kg} / \mathrm{ha}$, dan $200 \mathrm{~kg} / \mathrm{ha}$. Tata letak acak kelompok dengan empat blok sebagai ulangan. Data yang diperolah dianalisis menggunakan sidik ragam, bila ada beda nyata dilanjutkan dengan uji jarak ganda Duncan dengan taraf kesalahan $5 \%$. Hasil penelitian menunjukkan bahwa pemupukan Urea menurunkan kadar $\mathrm{N}$ daun. Tidak terdapat perbedaan takaran namun memberikan laju asimilasi bersih dengan takaran optimal $205 \mathrm{~kg} / \mathrm{ha}$. Pemupukan Urea tidak berpengaruh terhadap pertumbuhan dan hasil kedelai kultivar Anjasmoro.

Kata kunci : kedelai anjasmoro, tingkat takaran urea, nitrogen, pertumbuhan, hasil ekonomis 
Dhimas Ikhsan Prakoso et al., / Vegetalika. 2018. 7(3): 16-29

\section{PENDAHULUAN}

Kedelai merupakan tanaman penting di Indonesia karena merupakan sumber protein nabati yang baik dan berharga relatif murah. Sebagian besar biji kedelai diolah menjadi tahu dan tempe. Kedelai varietas unggul memiliki kadar protein biji hingga $39,2 \%$ per berat keringnya. Kedelai memiliki kandungan gizi lain yang terdiri dari $18 \%$ lemak, 24-36 \% karbohidrat, $8 \%$ air, asam amino dan kandungan gizi lainnya yang bermanfaat bagi manusia. Kandungan protein yang tinggi memerlukan pasokan nitrogen yang cukup. Kedelai mendapat nitrogen dari dua sumber yaitu dari simbiosis akar dengan bakteri Rhizobium dan dari pupuk nitrogen. Pemupukan nitrogen biasa diberikan dalam bentuk pupuk urea. Salah satu kultivar yang sering dipakai oleh petani Indonesia adalah kultivar Anjasmoro karena secara morfologi bijinya besar, mirip dengan ukuran kedelai impor, serta bersifat tidak mudah pecah dan tahan rebah. Kultivar Anjasmoro termasuk dalam jenis kedelai putih yang sering digunakan sebagai bahan baku makanan seperti tahu dan tempe.

Kedelai diketahui memiliki kemampuan untuk mengikat $\mathrm{N}_{2}$ di udara (bentuk $\mathrm{N}$ yang tidak tersedia bagi tanaman) karena bekerjasama dengan bakteri bintil akar atau Rhizobium di dalam tanah. Nitrogen tersebut kemudian dimanfaatkan oleh tanaman untuk mendukung siklus pertumbuhan dan perkembangan kedelai. Lebih lanjut, nitrogen yang diserap kemudian difungsikan sebagai bahan pembentukan biji pada proses fisiologis tanaman (Fabre dan Planchon, 2000). Produksi kedelai masih terkendala oleh teknologi yang digunakan petani dalam budidaya kedelai yang masih kurang baik. Kurang lebih $20 \%$ petani tidak menggunakan pupuk, $31 \%$ menggunakan pupuk organik dan anorganik, dan sisanya menggunakan pupuk anorganik saja.

Penggunaan pupuk anorganik dalam jumlah yang besar berdampak pada pengeluaran secara ekonomi. Upaya yang dapat dilakukan untuk mengurangi penggunaan pupuk anorganik dalam jumlah besar adalah dengan mengetahui takaran pemupukan yang sesuai dengan kebutuhan tanaman budidaya. Pemupukan yang tidak tepat dan berimbang dapat menyebabkan penurunan kemampuan tanaman untuk menyerap kandungan pupuk sehingga dampaknya dapat menurunkan hasil tanaman (Wood et al.,1993).

Pemupukan didefinisikan sebagai kegiatan penambahan bahan-bahan tertentu dalam rangka mengubah sifat fisik, kimia, atau biologi tanah sehingga menjadi lebih baik bagi pertumbuhan tanaman. Bahan-bahan tersebut mengandung satu atau lebih hara tanaman bergantung pada penyusunnya (Rosmarkam dan Yuwono, 2002). Urea merupakan salah satu pupuk anorganik tunggal yang memiliki kandungan nitrogen 
Dhimas Ikhsan Prakoso et al., / Vegetalika. 2018. 7(3): 16-29

pada bahan penyusunnya. Memiliki kandungan $\mathrm{N}$ sekitar $46 \%$, berbentuk kristal, dan memiliki tingkat higroskopis yang cukup tinggi sehingga mudah menyerap air dari udara jika disimpan dalam tempat terbuka.

Penggunaan takaran $50 \mathrm{~kg} / \mathrm{ha}$ urea pada tanaman kedelai telah direkomendasikan dan digunakan pada penelitian Krisnawati dan Adie (2015). Evaluasi pada 29 varietas kedelai dan hasil menunjukkan bahwa Anjasmoro memilki hasil yang lebih tinggi dari varietas lainnya dan termasuk dalam varietas yang memiliki bobot tajuk tertinggi. Pada penelitian Amir et al. (2015), kedelai yang dipupuk urea takaran 25 $\mathrm{kg} / \mathrm{ha}$ meningkatkan akumulasi $\mathrm{N}$ pada jaringan tanaman yang berdampak pada peningkatan laju fotosintesis dan hasil biji kedelai serta peningkatan kandungan protein biji. Pengaturan dosis pupuk urea pada tanaman kedelai merupakan upaya untuk mengoptimalkan hasil kedelai. Tujuan penelitian ini adalah untuk mengetahui pengaruh dosis pupuk urea yang diaplikasikan pada tanaman kedelai kultivar Anjasmoro terhadap pertumbuhan, perkembangan, dan hasil.

\section{BAHAN DAN METODE PENELITIAN}

Penelitian dilaksanakan di Kebun Percobaan Fakultas Pertanian UGM, Banguntapan Bantul, Yogyakarta pada bulan Juni sampai dengan bulan Desember 2016, terletak pada ketinggian 113 mdpl, berjenis tanah regosol. Alat yang digunakan antara lain, Spektrofotometer Spectronic $21 D$, timbangan digital, mortar, gelas beker, tabung raksi, oven, kaca preparat, dan kuteks. Bahan yang digunakan adalah kedelai varietas Anjasmoro, pupuk : Urea, $\mathrm{KCl}$, dan SP-36; pestisida untuk pengendalian OPT.

Penelitian ini disusun dengan menggunakan Rancangan Acak Kelompok Lengkap (RAKL) 4 ulangan. Perlakuan yaitu dosis pupuk urea yang terdiri dari lima aras : 0, 50, 100, 150, dan $200 \mathrm{~kg} / \mathrm{ha}$. Pupuk dasar SP-36 $100 \mathrm{~kg} / \mathrm{ha}$ dan $\mathrm{KCl} 75 \mathrm{~kg} / \mathrm{ha}$. Perlakuan diaplikasikan dengan dosis yang telah dikonversi menjadi ukuran luasan polibag. Pengaplikasian perlakuan dilakukan ketika tanaman berumur 2 mst. Variabel yang diamati meliputi tinggi tanaman, diameter batang, luas daun, berat kering batang, daun, akar, polong, dan biji, kandungan klorofil, kadar $\mathrm{N}$ total daun, kadar $\mathrm{N}$ total tanah, konduktivitas stomata. Data pengamatan yang diperoleh dianalisis dengan sidik ragam, bila ada beda nyata pada hasil analisis, dilanjutkan dengan uji jarak ganda duncan pada taraf $5 \%$. 


\section{HASIL DAN PEMBAHASAN}

Tanah yang digunakan dalam penelitian merupakan tanah jenis regosol yang secara umum memiliki terkstur geluh lempung pasiran. Tanah yang digunakan dalam penelitian sebelum dipupuk memiliki nilai $\mathrm{N}$ yang sangat rendah yaitu $0,07 \%$. Sampel tanah dianalisis di Laboratorium BPTP Yogyakarta.

Tabel 1. Kadar $\mathrm{N}$ tanah (\%) awal dan akhir

\begin{tabular}{ccccc}
\hline $\begin{array}{c}\text { Pupuk Urea } \\
\text { (kg/ha) }\end{array}$ & $\begin{array}{c}\text { N Tanah Sebelum } \\
\text { Perlakuan (\%) } \\
\text { (Komposit) }\end{array}$ & $\begin{array}{c}\text { Harkat } \\
\text { Tanah* }^{*}\end{array}$ & $\begin{array}{c}\text { N Tanah } \\
\text { Setelah } \\
\text { Panen (\%) }\end{array}$ & Harkat Tanah* \\
\hline 0 & & & $0,063 \mathrm{a}$ & Sangat rendah \\
50 & 0,07 & $\begin{array}{c}\text { Sangat } \\
\text { rendah }\end{array}$ & $0,070 \mathrm{a}$ & $\begin{array}{c}\text { Sangat rendah } \\
100\end{array}$ \\
150 & & $0,064 \mathrm{a}$ & Sangat rendah \\
200 & & $0,060 \mathrm{a}$ & Sangat rendah \\
\hline Koefisien & - & $11,14 \%$ & \\
keragaman & & & \\
\hline
\end{tabular}

${ }^{*}$ Harkat tanah dari (Rosmarkam dan Yuwono, 2002)

Hasil kandungan $\mathrm{N}$ tanah setelah dipupuk menunjukkan bahwa tidak ada perbedaan yang signifikan antar perlakuan dosis pupuk (Tabel 1). Pemupukan urea pada tanaman kedelai Anjasmoro pada masing-masing dosis perlakuan tidak memberikan pengaruh pada akumulasi $\mathrm{N}$ tanah.

Tabel 2. Kandungan Nitrogen total daun kedelai Anjasmoro umur 4 dan 8 mst pada berbagai dosis pemupukan $\mathrm{N}$

\begin{tabular}{ccc}
\hline \multirow{2}{*}{ Pupuk N (kg/ha) } & \multicolumn{2}{c}{ Kandungan N total Daun } \\
\cline { 2 - 3 } & $4 \mathrm{mst}$ & $8 \mathrm{mst}$ \\
\hline 0 & $3,62 \mathrm{a}$ & $3,72 \mathrm{a}$ \\
50 & $3,96 \mathrm{a}$ & $2,31 \mathrm{~b}$ \\
100 & $3,98 \mathrm{a}$ & $2,49 \mathrm{~b}$ \\
150 & $4,06 \mathrm{a}$ & $2,76 \mathrm{~b}$ \\
200 & $3,73 \mathrm{a}$ & $2,71 \mathrm{~b}$ \\
\hline
\end{tabular}

Koefisien keragaman $\quad 8,03 \% \quad 18,3 \%$

Keterangan: Angka yang diikuti huruf sama pada kolom sama menunjukan tidak ada berbeda nyata berdasarkan uji lanjut Duncan's Multiple Range Test taraf $5 \%$.

Hasil analisis menunjukkan bahwa pemupukan urea belum mempengaruhi kandungan $\mathrm{N}$ total daun pada umur $4 \mathrm{mst}$. Pada umur $8 \mathrm{mst}$, pemupukan urea memberikan pengaruh pada kandungan $\mathrm{N}$ total daun, namun perbedaan dosis tidak menunjukkan adanya perbedaan. Pemupukan urea justru menyebabkan penurunan kandungan $\mathrm{N}$ daun (Tabel 2). 
Dhimas Ikhsan Prakoso et al., / Vegetalika. 2018. 7(3): 16-29

Hasil analisis statistik menunjukkan bahwa pemberian pupuk urea tidak memberikan perbedaan yang nyata terhadap kadar klorofil a, b, dan klorofil total 4 dan 8 mst (Tabel 3). Perbedaan dosis pemupukan urea tidak memberikan pengaruh pada perubahan kandungan klorofil yang terdapat pada daun. Taiz dan Zeiger (2002) menjelaskan bahwa dalam daun terdapat kloroplas yang terdiri dari pigmen hijau daun berfungsi untuk absorpsi cahaya dan terkandung dalam jaringan mesofil.

Tabel 3. Kandungan klorofil a, b, dan total kedelai Anjasmoro umur 4 dan 8 mst pada berbagai dosis pemupukan $\mathrm{N}$

\begin{tabular}{ccccccc}
\hline \multirow{2}{*}{ Pupuk N (kg/ha) } & \multicolumn{2}{c}{$\begin{array}{c}\text { Klorofil a (mg/g bobot } \\
\text { segar) }\end{array}$} & \multicolumn{2}{c}{$\begin{array}{c}\text { Klorofil b }(\mathrm{mg} / \mathrm{g} \\
\text { bobot segar) }\end{array}$} & \multicolumn{2}{c}{$\begin{array}{c}\text { Klorofil total }(\mathrm{mg} / \mathrm{g} \\
\text { bobot segar) }\end{array}$} \\
\cline { 2 - 7 } & $4 \mathrm{mst}$ & $8 \mathrm{mst}$ & $4 \mathrm{mst}$ & $8 \mathrm{mst}$ & $4 \mathrm{mst}$ & $8 \mathrm{mst}$ \\
\hline 0 & $0,017 \mathrm{a}$ & $0,018 \mathrm{a}$ & $0,016 \mathrm{a}$ & $0,019 \mathrm{a}$ & $0,033 \mathrm{a}$ & $0,038 \mathrm{a}$ \\
50 & $0,017 \mathrm{a}$ & $0,017 \mathrm{a}$ & $0,019 \mathrm{a}$ & $0,018 \mathrm{a}$ & $0,036 \mathrm{a}$ & $0,034 \mathrm{a}$ \\
100 & $0,019 \mathrm{a}$ & $0,018 \mathrm{a}$ & $0,021 \mathrm{a}$ & $0,020 \mathrm{a}$ & $0,041 \mathrm{a}$ & $0,038 \mathrm{a}$ \\
150 & $0,017 \mathrm{a}$ & $0,018 \mathrm{a}$ & $0,017 \mathrm{a}$ & $0,018 \mathrm{a}$ & $0,034 \mathrm{a}$ & $0,036 \mathrm{a}$ \\
200 & $0,014 \mathrm{a}$ & $0,018 \mathrm{a}$ & $0,015 \mathrm{a}$ & $0,020 \mathrm{a}$ & $0,029 \mathrm{a}$ & $0,039 \mathrm{a}$ \\
\hline $\begin{array}{c}\text { Koefisien } \\
\text { keragaman }\end{array}$ & $18,23 \%$ & $8,13 \%$ & $22,15 \%$ & $12,95 \%$ & $19,95 \%$ & $10,36 \%$ \\
\hline
\end{tabular}

Keterangan: Angka yang diikuti huruf sama pada kolom sama menunjukan tidak ada berbeda nyata berdasarkan uji lanjut Duncan's Multiple Range Test taraf $5 \%$.

Tabel 4. Bobot daun khas kedelai Anjasmoro umur 4, 8, dan 12 mst pada berbagai dosis pemupukan $\mathrm{N}$

\begin{tabular}{cccc}
\hline \multirow{2}{*}{ Pupuk N (kg/ha) } & \multicolumn{3}{c}{ Bobot Daun Khas $\left(\mathrm{g} / \mathrm{dm}^{2}\right)$} \\
\cline { 2 - 4 } & $4 \mathrm{mst}$ & $8 \mathrm{mst}$ & $12 \mathrm{mst}$ \\
\hline 0 & $0,54 \mathrm{a}$ & $0,37 \mathrm{a}$ & $0,43 \mathrm{a}$ \\
50 & $0,38 \mathrm{a}$ & $0,38 \mathrm{a}$ & $0,43 \mathrm{a}$ \\
100 & $0,44 \mathrm{a}$ & $0,35 \mathrm{a}$ & $0,46 \mathrm{a}$ \\
150 & $0,46 \mathrm{a}$ & $0,43 \mathrm{a}$ & $0,39 \mathrm{a}$ \\
200 & $0,41 \mathrm{a}$ & $0,37 \mathrm{a}$ & $0,45 \mathrm{a}$ \\
\hline Koefisien keragaman & $18,66 \%$ & $10,88 \%$ & $17,84 \%$
\end{tabular}

Keterangan: Angka yang diikuti huruf sama pada kolom sama menunjukan tidak ada berbeda nyata berdasarkan uji lanjut Duncan's Multiple Range Test taraf $5 \%$.

Tabel 4 menunjukkan hasil analisis tidak ada beda nyata pada bobot daun khas tanaman kedelai Anjasmoro di semua dosis pemupukan $\mathrm{N}$ umur 4, 8, maupun 12 mst. Bobot daun khas menunjukkan ketebalan daun dalam suatu cakupan tanaman. Ketebalan daun didominasi oleh jaringan daun yaitu mesofil. Sebagai tempat yang paling aktif dalam melakukan fotosintesis, mesofil mengambil peran dalam membentuk asimilat tanaman 
Dhimas Ikhsan Prakoso et al., / Vegetalika. 2018. 7(3): 16-29

Tabel 5. Laju Asimilasi Bersih 4-8 mst kedelai Anjasmoro pada berbagai dosis pemupukan $\mathrm{N}$

\begin{tabular}{cc}
\hline \multirow{2}{*}{ Pupuk N (kg/ha) } & $\begin{array}{c}\text { Laju Asimilasi Bersih } \\
\left(\mathrm{g} / \mathrm{dm}^{2} / \mathrm{ming}\right)\end{array}$ \\
\cline { 2 - 2 } & $4-8 \mathrm{mst}$ \\
\hline 0 & $0,46 \mathrm{~b}$ \\
50 & $0,49 \mathrm{~b}$ \\
100 & $0,50 \mathrm{~b}$ \\
150 & $0,79 \mathrm{a}$ \\
200 & $0,64 \mathrm{ab}$ \\
\hline
\end{tabular}

Koefisien keragaman 24,51\%

Keterangan: Angka yang diikuti huruf sama pada kolom sama menunjukan tidak ada berbeda nyata berdasarkan uji lanjut Duncan's Multiple Range Test taraf $5 \%$.

Pada Tabel 5, hasil analisis menunjukkan bahwa pemupukan urea berpengaruh secara nyata terhadap laju asimilasi bersih kedelai 4-8 mst. Laju asimilasi bersih sering dikaitkan dengan laju pertumbuhan nisbi. Laju pertumbuhan nisbi menunjukkan kemampuan tanaman dalam menghasilkan asimilat pada interval waktu tertentu dalam hubungannya dengan berat asal (Gardner, 2008). Pada awal pertumbuhannya, tanaman yang dipupuk urea cenderung lebih efisien dalam melakukan asimilasi namun hal tersebut tidak mempengaruhi pembentukan bahan keringnya di umur yang sama.

Tabel 6. Luas daun $\left(\mathrm{dm}^{2}\right)$ kedelai Anjasmoro pada berbagai dosis pupuk urea umur 4, 8, dan 12 mst

\begin{tabular}{crrr}
\hline \multirow{2}{*}{ Pupuk Urea $(\mathrm{kg} / \mathrm{ha})$} & \multicolumn{3}{c}{ Luas Daun $\left(\mathrm{dm}^{2}\right)$} \\
\cline { 2 - 4 } & $4 \mathrm{mst}$ & $8 \mathrm{mst}$ & $12 \mathrm{mst}$ \\
\hline 0 & $2,588 \mathrm{a}$ & 21,961 & $15,098 \mathrm{a}$ \\
& $\mathrm{a}$ & \\
50 & $3,192 \mathrm{a}$ & 24,481 & $15,956 \mathrm{a}$ \\
& $\mathrm{a}$ & \\
100 & $3,702 \mathrm{a}$ & 27,356 & $12,708 \mathrm{a}$ \\
& $\mathrm{a}$ & \\
150 & $1,617 \mathrm{a}$ & 21,557 & $9,287 \mathrm{a}$ \\
& & $\mathrm{a}$ \\
200 & $2,256 \mathrm{a}$ & 25,907 & $12,603 \mathrm{a}$ \\
& & $\mathrm{a}$ \\
\hline Koefisien keragaman & $9,66 \%$ * & $17,99 \%$ & $34,87 \%$ \\
\hline
\end{tabular}

Keterangan: Angka yang diikuti huruf sama pada kolom sama menunjukan tidak ada berbeda nyata berdasarkan uji lanjut Duncan's Multiple Range Test taraf $5 \%$. *Data ditransformasi menggunakan $\log (\mathrm{x})$ 
Dhimas Ikhsan Prakoso et al., / Vegetalika. 2018. 7(3): 16-29

\section{Laju Asimilasi Bersih 4-8 mst}

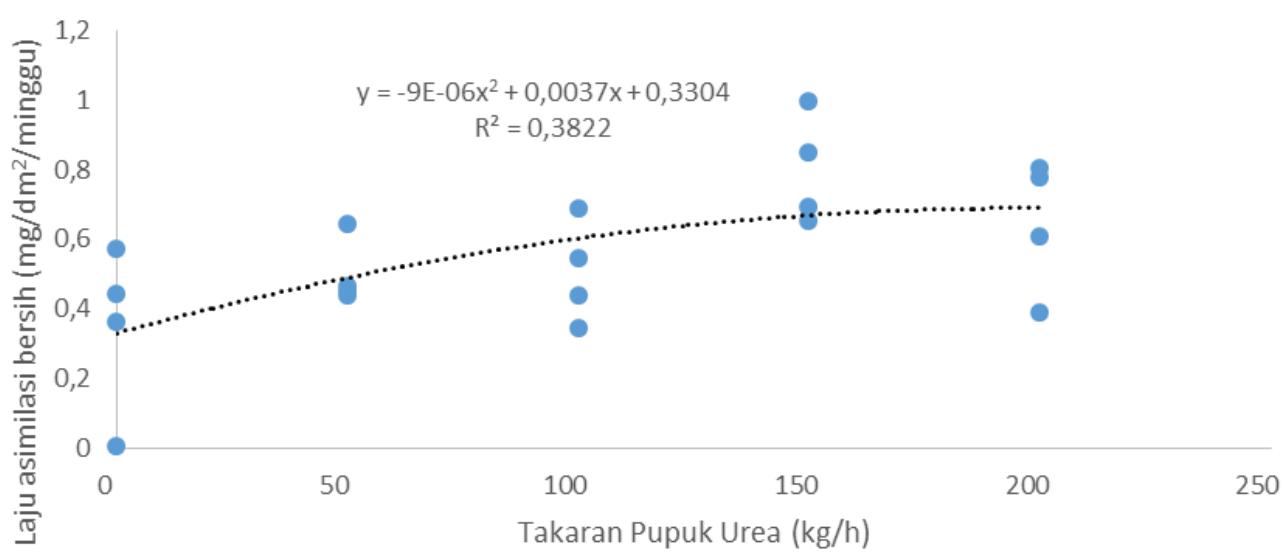

Gambar 1. Regresi laju asimilasi bersih kedelai Anjasmoro umur 4-8 mst

Laju fotosintesis per satuan tanaman sebagian besar ditentukan oleh luas daun sehingga infromasi mengenai kemampuan fotosintesis tanaman dapat diperoleh melalui pengamatan luas daun. Hasil analisis statistik menunjukkan bahwa pemupukan urea tidak mempengaruhi luas daun secara nyata di setiap tingkat perlakuan pada umur 4, 8, dan 12 mst (Tabel 6). Baik tanaman yang dipupuk urea maupun tidak dipupuk urea memberikan luas daun yang sama di semua umur pengamatan. Luas daun yang sama antar tanaman kemudian diduga menyebabkan kemampuan tanaman menghasilkan asimilat per bobot keringnya menjadi terhambat. Hal ini ditunjukkan oleh nilai laju pertumbuhan nisbi kedelai.

Tabel 7. Laju pertumbuhan nisbi kedelai Anjasmoro umur 4-8 dan 8-12 mst pada berbagai dosis pemupukan $\mathrm{N}$

\begin{tabular}{ccc}
\hline \multirow{2}{*}{ Pupuk N (kg/ha) } & \multicolumn{2}{c}{$\begin{array}{c}\text { Laju Pertumbuhan Nisbi } \\
\text { (gram/gram/minggu) }\end{array}$} \\
\cline { 2 - 3 } & $4-8 \mathrm{mst}$ & $8-12 \mathrm{mst}$ \\
\hline 0 & $0,45 \mathrm{a}$ & $3,18 \mathrm{a}$ \\
50 & $0,51 \mathrm{a}$ & $3,05 \mathrm{a}$ \\
100 & $0,49 \mathrm{a}$ & $3,07 \mathrm{a}$ \\
150 & $0,66 \mathrm{a}$ & $2,65 \mathrm{a}$ \\
200 & $0,61 \mathrm{a}$ & $2,87 \mathrm{a}$ \\
\hline Koefisien keragaman & $19,91 \%$ & $10,51 \%$ \\
\hline
\end{tabular}

Keterangan: Angka yang diikuti huruf sama pada kolom sama menunjukan tidak ada berbeda nyata berdasarkan uji lanjut Duncan's Multiple Range Test taraf $5 \%$.

Tabel 8 menunjukkan bobot kering total tanaman kedelai Anjasmoro. Pemupukan urea tidak memberikan perbedaan pengaruh terhadap bobot kering total 
Dhimas Ikhsan Prakoso et al., / Vegetalika. 2018. 7(3): 16-29

tanaman kedelai. Akumulasi asimilat pada setiap tanaman ketika diberikan tambahan pupuk tidak menunjukkan perbedaan. Artinya pemberian pupuk urea diduga tidak memberikan dampak pada penimbunan asimilat keseluruhan

Tabel 8. Bobot kering total $(\mathrm{g})$ kedelai Anjasmoro pada berbagai dosis pemupukan urea pada umur 4, 8, dan 12 mst.

\begin{tabular}{cccc}
\hline \multirow{2}{*}{ Pupuk N (kg/ha) } & \multicolumn{3}{c}{ Bobot Kering Total (g) } \\
\cline { 2 - 4 } & $4 \mathrm{mst}$ & $8 \mathrm{mst}$ & $12 \mathrm{mst}$ \\
\hline 0 & $3,32 \mathrm{a}$ & $19,91 \mathrm{a}$ & $19,37 \mathrm{a}$ \\
50 & $3,27 \mathrm{a}$ & $23,65 \mathrm{a}$ & $20,13 \mathrm{a}$ \\
100 & $3,81 \mathrm{a}$ & $25,29 \mathrm{a}$ & $19,73 \mathrm{a}$ \\
150 & $1,81 \mathrm{a}$ & $24,98 \mathrm{a}$ & $14,27 \mathrm{a}$ \\
200 & $2,42 \mathrm{a}$ & $26,36 \mathrm{a}$ & $19,13 \mathrm{a}$ \\
\hline Koefisien keragaman & $8,29 \%$ * & $19,82 \%$ & $29.55 \%$
\end{tabular}

Keterangan: Angka yang diikuti huruf sama pada kolom sama menunjukan tidak ada beda nyata berdasarkan uji lanjut Duncan's Multiple Range Test taraf $5 \%$. ${ }^{*}$ Data ditransformasi menggunakan sqrt $(x+4)$

Hasil dari proses pertumbuhan dan perkembangan tanaman digambarkan melalui parameter tinggi tanaman dan diameter batang. Pertumbuhan tinggi tanaman dan diameter batang membentuk pola sigmoid seiring dengan bertambahnya waktu (Gambar 2 dan 3). Dari awal pertumbuhan, tinggi tanaman pada dosis pupuk 100 $\mathrm{kg} / \mathrm{ha}$ sudah menunjukkan tren yang lebih tinggi dibandingkan dengan dosis lainnya. Tanaman berdiameter batang terbesar yaitu pada dosis pemupukan $100 \mathrm{~kg} / \mathrm{ha}$. Di awal pertumbuhan, dosis $50 \mathrm{~kg} / \mathrm{ha}$ menujukkan diameter yang lebih besar dibanding perlakuan lainnya. Namun, tren mengalami perubahan ketika memasuki umur 5-8 mst. 
Dhimas Ikhsan Prakoso et al., / Vegetalika. 2018. 7(3): 16-29

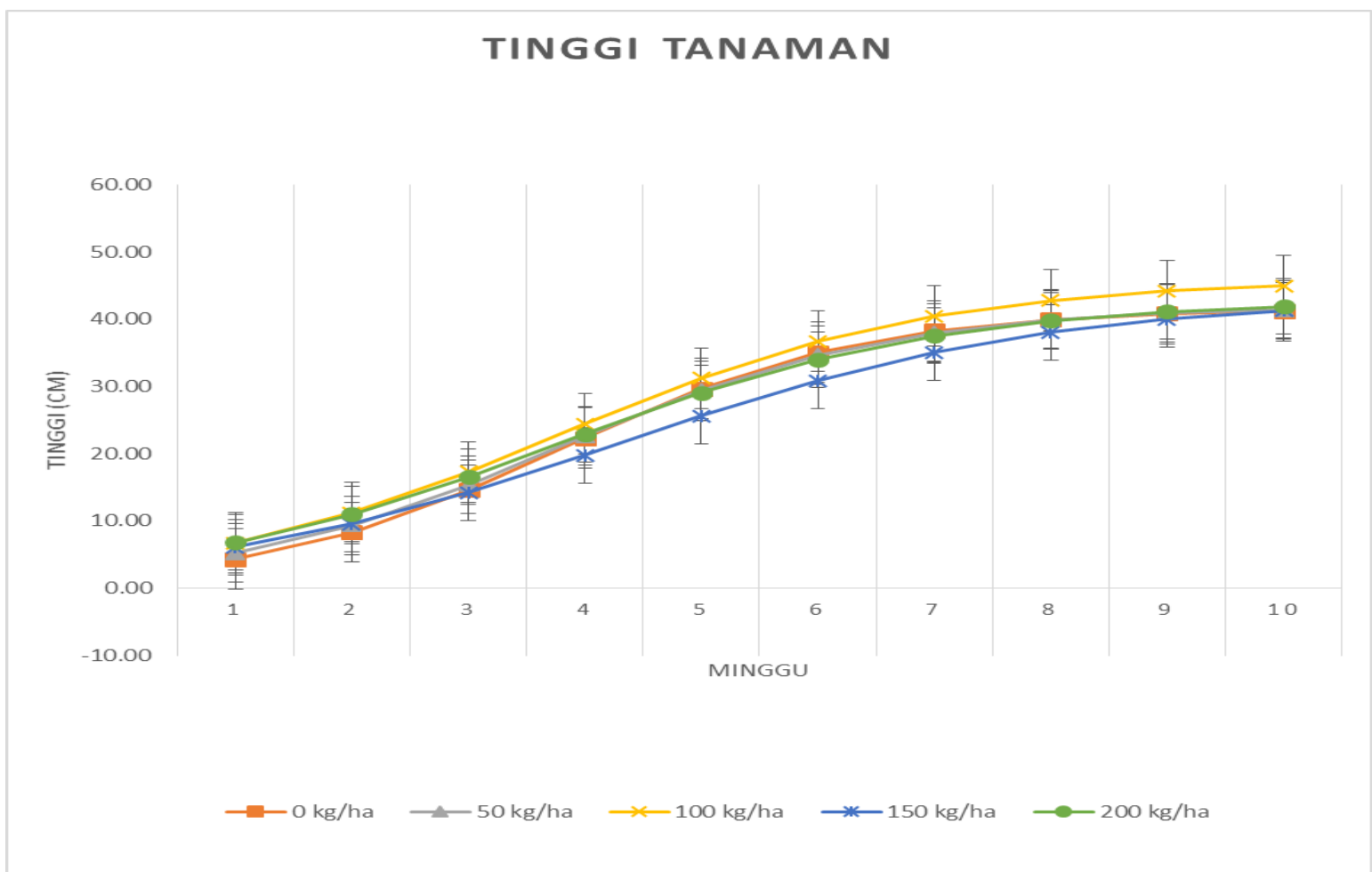

Gambar 2. Dinamika pertumbuhan tinggi tanaman kedelai Anjasmoro 1 - 10 mst pada berbagai dosis pemupukan urea

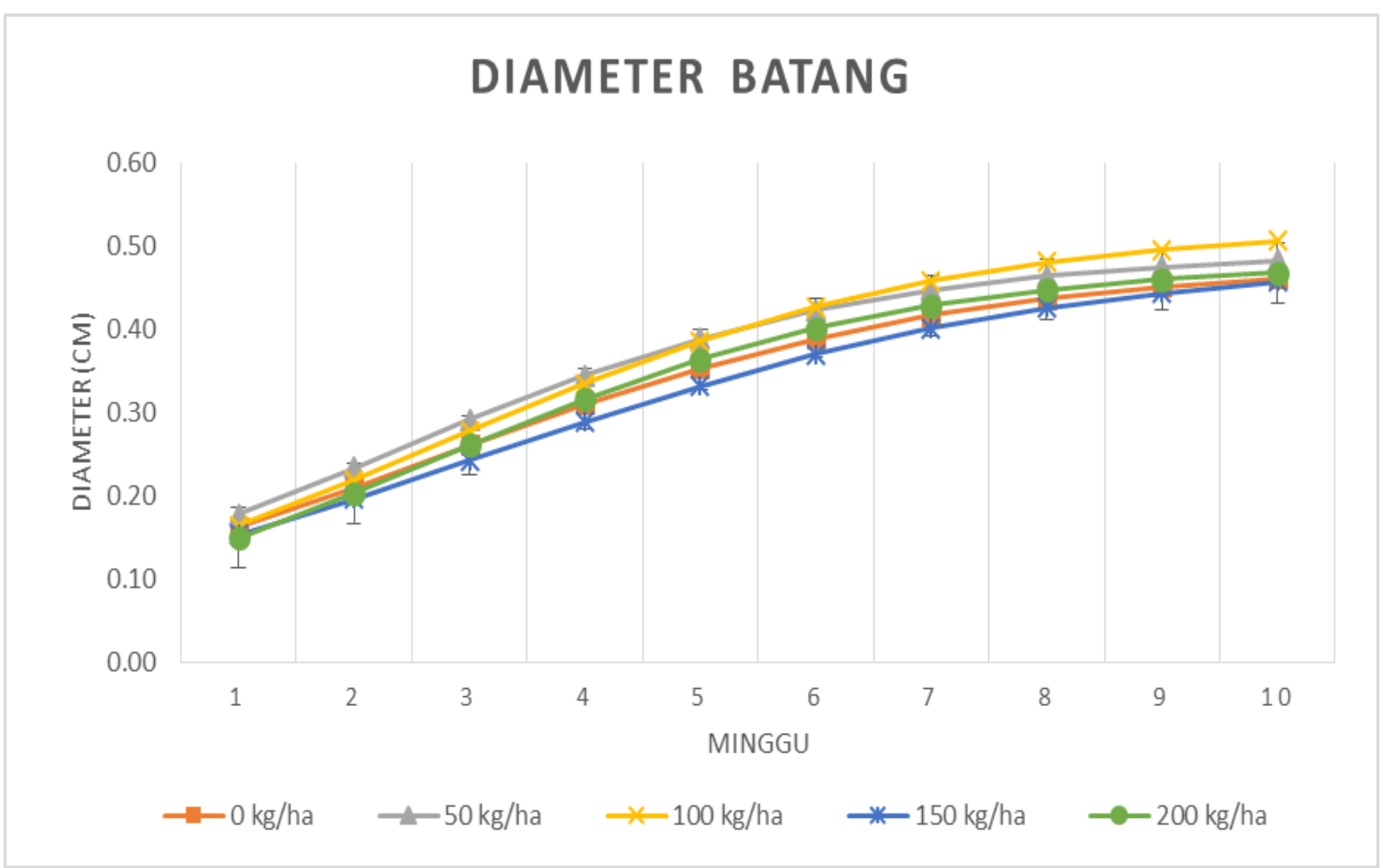

Gambar 3. Dinamika pertumbuhan diameter batang tanaman kedelai Anjasmoro $1-10 \mathrm{mst}$ pada berbagai dosis pemupukan 
Dhimas Ikhsan Prakoso et al., / Vegetalika. 2018. 7(3): 16-29

Indeks panen menunjukkan perbandingan distribusi hasil asimilasi antara biomassa ekonomi dengan biomassa keseluruhan (Gardner et al., 2008). Hasil analisis statistik menunjukkan perlakuan pemupukan urea pada tanaman kedelai Anjasmoro tidak memberikan perbedaan pengaruh yang nyata terhadap indeks panen. Hal ini menggambarkan bahwa setiap dosis pemupukan urea memberikan pengaruh yang sama pada tanaman dalam hal pendistribusian hasil asimilasi ke organ ekonomis.

Tabel 9. Indeks Panen kedelai Anjasmoro pada berbagai dosis pemupukan urea

\begin{tabular}{cc}
\hline Pupuk N $(\mathrm{kg} / \mathrm{ha})$ & Indeks Panen \\
\hline 0 & $0,53 \mathrm{a}$ \\
50 & $0,51 \mathrm{a}$ \\
100 & $0,51 \mathrm{a}$ \\
150 & $0,48 \mathrm{a}$ \\
200 & $0,41 \mathrm{a}$ \\
\hline
\end{tabular}

Koefisien keragaman $16,03 \%$

Keterangan: Angka yang diikuti huruf sama pada kolom sama menunjukan tidak ada berbeda nyata berdasarkan uji lanjut Duncan's Multiple Range Test taraf $5 \%$.

Tabel 10 menunjukkan hasil bobot kering biji kedelai antar perlakuan dosis pupuk urea. Tidak ada perbedaan yang signifikan pada bobot kering biji kedelai di semua dosis perlakuan. Diindikasikan bahwa pada kedelai Anjasmoro, pemupukan urea tidak berpengaruh nyata pada pembentukan biji. Analisis statistik menunjukkan bahwa tidak ada beda nyata bobot kering 100 biji pada semua perlakuan dosis pemupukan.

Tabel 10. Bobot kering biji kedelai Anjasmoro berbagai dosis pemupukan urea pada umur 12 mst

\begin{tabular}{cc}
\hline Pupuk N (kg/ha) & Bobot Kering Biji (g) \\
\hline 0 & $21,51 \mathrm{a}$ \\
50 & $20,59 \mathrm{a}$ \\
100 & $20,32 \mathrm{a}$ \\
150 & $20,32 \mathrm{a}$ \\
200 & $15,07 \mathrm{a}$ \\
\hline Koefisien keragaman & $7,77 \%{ }^{*}$ \\
\hline
\end{tabular}

Keterangan: Angka yang diikuti huruf sama pada kolom sama menunjukan tidak ada berbeda nyata berdasarkan uji lanjut Duncan's Multiple Range Test taraf $5 \%$. ${ }^{*}$ Data ditransformasi menggunakan log $(x+10)$

Tabel 11 menunjukkan hasil analisis bobot kering 100 biji berbagai dosis pemupukan urea pada berbagai umur. Menurut Kuswantoro (2010), bobot 100 biji menggambarkan ukuran biji kedelai. Bobot kering 100 biji ditentukan dengan bentuk biji yang berisi, tanpa cacat, tidak pucat, dan bentuk bagus (bulat sempurna). Hasil menunjukkan bahwa tidak ada beda nyata bobot kering 100 biji pada semua perlakuan 
Dhimas Ikhsan Prakoso et al., / Vegetalika. 2018. 7(3): 16-29

dosis pemupukan. Hal ini menunjukkan pemupukan urea tidak berpengaruh terhadap perubahan bobot kering biji kedelai Anjasmoro dalam berbagai dosis pemupukan urea.

Tabel 11. Bobot kering 100 biji kedelai Anjasmoro pada berbagai dosis pemupukan.

\begin{tabular}{cc}
\hline Pupuk Urea $(\mathrm{kg} / \mathrm{ha})$ & Bobot Kering $100 \mathrm{Biji}(\mathrm{g})$ \\
\hline 0 & $14,97 \mathrm{a}$ \\
50 & $14,86 \mathrm{a}$ \\
100 & $15,92 \mathrm{a}$ \\
150 & $14,91 \mathrm{a}$ \\
200 & $12,70 \mathrm{a}$ \\
\hline Koefisien keragaman & $15,82 \%$ \\
\hline
\end{tabular}

Keterangan: Angka yang diikuti huruf sama pada kolom sama menunjukan tidak ada berbeda nyata berdasarkan uji lanjut Duncan's Multiple Range Test taraf $5 \%$.

Anjasmoro merupakan kultivar tanaman kedelai yang sering digunakan oleh petani di lahan. Berdasarkan penelitian yang dilakukan oleh Sumarmi et al. (2014), Anjasmoro merupakan salah satu dari tiga kultivar yang mempunyai ukuran biji bulat besar. Berangkat dari karakterisitik tersebut, kedelai Anjasmoro diduga pada awal pertumbuhannya mampu untuk menghasilkan energi yang lebih besar untuk tumbuh.

Kandungan $\mathrm{N}$ yang sama pada media tumbuh tanaman diduga berdampak pada kadar $\mathrm{N}$ total jaringan daun. Nitrogen yang diserap ketika ditambahkan pupuk urea diduga tidak terakumulasi dengan baik. Hal ini dilihat dari tanaman pada umur 8 mst, pemberian pupuk urea sampai dosis $200 \mathrm{~kg} / \mathrm{h}$ menurunkan kadar $\mathrm{N}$ total pada jaringan daun (Tabel 2). Nitrogen dibutuhkan tanaman guna sintesis protein namun secara struktural merupakan bagian dari klorofil (Amir et al., 2015). Hal yang sama terjadi pada bobot daun khas. Pemberian dosis pupuk urea tidak berdampak pada peningkatan maupun penurunan bobot daun khas antar tanaman. Bobot daun khas berkaitan dengan ketebalan daun. Bobot daun khas yang tidak berbeda antar tanaman secara analisis mengindikasikan tiap-tiap tanaman memiliki ketebalan daun yang sama.

Hal yang menarik, laju asimilasi bersih pada 4-8 mst lebih tinggi yakni pada tanaman yang dipupuk $150 \mathrm{~kg} / \mathrm{ha}$. Namun, laju asimilasi yang tinggi tidak mempengaruhi pertumbuhan nisbinya. Pada umur yang sama, kemampuan tanaman dalam menghasilkan asimilat menunjukkan hasil yang sama pada tanaman kedelai Anjasmoro. Hal ini menyiratkan bahwa efisiensi tanaman dalam menghasilkan asimilat tidak mendukung pemanfaatan asimilat oleh tanaman untuk pertumbuhan organ. Sehingga, dapat dikatakan bahwa tanaman yang diberikan pupuk dosis $150 \mathrm{~kg} / \mathrm{ha}$ lebih efisien dalam membentuk asimilat, namun penambahan pupuk menurunkan 
Dhimas Ikhsan Prakoso et al., / Vegetalika. 2018. 7(3): 16-29

kemampuan efisiensinya. Hal ini kemudian berakibat pada penimbunan asimilat yang ditunjukkan oleh bobot kering total. Secara umum, penimbunan asimilat pada organorgan tanaman kedelai Anjasmoro tidak mengalami dampak yang signifikan menurun atau meningkat oleh perbedaan dosis pemupukan urea.

Bertambahnya umur tanaman menunjukkan tanaman melakukan pembesaran dan penambahan ukuran jumlah serta ukuran sel. Hal tersebut salah satunya digambarkan melalui tinggi tanaman dan diameter batang. Pada tanaman yang diberi dosis 50 dan $100 \mathrm{~kg} / \mathrm{ha}$, pada awal pertumbuhan memiliki nilai yang tinggi untuk pertumbuhan tinggi dan diameter batangnya. Penelitian Sumarmi et al. (2014) juga menunjukkan bahwa tanaman kedelai Anjasmoro memiliki nilai pertumbuhan tinggi tanaman yang lebih besar dibanding kultivar lain yang diuji coba.

Indeks panen merupakan perbandingan translokasi asimilat yang didistribusikan ke arah biomassa ekonomis dengan biomassa tanaman keseluruhan. Pemberian pupuk urea pada berbagai tingkat dosis secara umum memberikan pengaruh yang sama pada penambahan biomassa ekonomis (Tabel 9). Namun, nilai indeks panen menurun ketika dosis pupuk urea semakin tinggi. Artinya, penambahan pupuk urea pada dosis yang tinggi diduga menurunkan indeks panen dimana pendistribusian hasil asimilat sebagian besar diarahkan ke organ vegetatif.

Selain itu, pemberian pupuk $\mathrm{N}$ yang tinggi dapat memicu adanya persaingan antara sintesis karbohidrat dan protein. Pada penelitian yang dilakukan oleh Johnson et al. (2013), hubungan yang kontradiktif antara konsentrasi protein ketika metabolisme karbohidrat ditemukan pada tanaman Brassica Carinata. Hal ini juga terjadi pada tanaman kedelai, dimana pemberian pupuk urea pada dosis $179 \mathrm{~kg} / \mathrm{ha}$ pada tahap pertumbuhan awal menurunkan kadar protein pada biji (Kaur et al., 2017). Sehingga dapat saja dimungkinkan rendahnya hasil biji ketika ditambahkan pupuk urea disebabkan adanya persaingan antara sintesis karbohidrat dan protein pada tanaman kedelai yang diberikan pupuk dengan dosis diatas $100 \mathrm{~kg} / \mathrm{ha}$, berawal dari kandungan klorofil yang sama pada setiap tanaman.

Penelitian yang dilakukan oleh Li et al. (2012), mengungkapkan bahwa bobot daun khas, kadar klorofil, dan laju asimilasi bersih lebih tinggi pada varietas kedelai hasil panen tinggi dibandingkan dengan varietas hasil panen rendah dengan kondisi lingkungan yang sama. Hal ini mendukung pernyataan bahwa tanaman kedelai kultivar Anjasmoro dimungkinkan untuk menggunakan dosis pupuk urea dalam jumlah yang rendah atau tidak dilakukan pemberian sama sekali, melihat dari kemampuan fisiologis dan morfologinya yang baik. Pemberian urea dilakukan pada saat tanaman masih 
Dhimas Ikhsan Prakoso et al., / Vegetalika. 2018. 7(3): 16-29

dalam fase pertumbuhan awal atau pada umur dua minggu meningkatkan kemampuan tanaman dalam efisiensi berfotosintesis, namun peningkatan dosis yang lebih tinggi menurunkan hasil biji.

\section{KESIMPULAN}

1. Pemupukan Urea menurunkan kadar $\mathrm{N}$ daun. Tidak terdapat pengaruh perbedaan dosis, namun pemupukan Urea memberikan laju asimilasi bersih dengan dosis optimal 205,5 kg/ha.

2. Pemupukan Urea tidak berpengaruh terhadap pertumbuhan dan hasil kedelai kultivar Anjasmoro.

\section{DAFTAR PUSTAKA}

Amir, B., D. Indradewa, dan E. T. S. Putra. 2015. Hubungan bintil akar dan aktivitas nitrat reduktase dengan serapan N pada beberapa kultivar kedelai (Glycine max). Semnas Masy Biodiv Indonesia Vol 1, No. 5 hal 1132-1135. doi: 10.13057/psnmbi/m010528.

Fabre F. dan C. Planchon. 2000. Nitrogen nutrition, yield, and protein content in soybean. Plant Science $152:$ 51-58.

Gardner, F. P., R. B. Pearce, dan R. L. Mitchell. 2008. Fisiologi Tanaman Budidaya Universitas Indonesia Press. Jakarta.

Kaur, G., W. R. Serson, J. M. Orlowski, J. M. McCoy, B.R. Golden dan N. Bellaoui. 2017. Nitrogen sources and rates affect soybean seed composition in Mississipi. Article Agronomy doi : 10.3390/agronomy7040077.

Krisnawati, A. dan M. M. Adie. 2015. Variability of Biomass and Harvest Index from Several Soybean Genotypes as Renewable Energy Source. Energy Procedia 65 :14-21.

Li, Da-yong., Z. Zhi-an, Z. Dian-jun, J. Li-yan, W. Yuan-li. 2012. Comparison of net photosinthetic rate in leaves of soybean with different yield levels. Abstract. Journal of Northest Agricultural University $19: 14-19$.

Rosmarkam, A. dan N. W. Yuwono. 2002. Ilmu Kesuburan Tanah. Kanisius. Yogyakarta.

Sumarmi., B.D. Daryono, D. Rachmawati, A. Indrianto. 2014. Determination of soybean (Glycine max L.) microspores development stage based on the length of flower buds. Joural of Biological Researches : 20 (6-11).

Taiz, L dan E. Zeiger. 2002. Plant Physiology, 3rd ed. Annals Botany Company. United States of America. 
Dhimas Ikhsan Prakoso et al., / Vegetalika. 2018. 7(3): 16-29

Wood, C. W., D. W. Reeves, dan D. G. Himelrick. 1993. Relationship between chlorophyll meter reading and leaf chlorophyll, $\mathrm{N}$ status, and crop yield: $\mathrm{A}$ Review. Proceeding Agronomy Society of New Zealand. 